\title{
A Genetic Study on the Local Populations in Mie Prefecture
}

\author{
IV. The genetic relations among the Kamishima, Toshi, \\ Momotori and Toba populations*
}

\author{
Kazumichi Katayama and Tasuku TOYOMASU \\ Department of Legal Medicine, Osaka Medical School
}

\begin{abstract}
Using the measures of genetic, migrational, and geographic distances, the population structure was analyzed of populations in Kamishima, Toshi, Momotori and Toba, Mie Prefecture, to clarify the population genetic relationships among these populations. In order to measure the migrational distance relationships between the populations, a new statistic based on surname distributions was adopted. The genetic distance relationships were estimated by the method of HARPENDING \& JENKINS (1973) and the analysis was based on the variability in 10 blood group, serum protein and red cell enzyme systems. Further, in order to give a visual interpretation of these distance matrices, diagrams were represented based on genetic affinity and dendrograms were reconstructed based on both genetic and migrational distances. Finally, the correlations between genetic, migrational, and geographic distances separating the populations were examined.

It is concluded that half of the genetic diversity among these populations may reflect the variation caused by inter-populational migration and the remaining half may correspond to random variation.
\end{abstract}

It has been said that the analysis of population structure is essentially a comparison among different types of distance measure : biological, geographical, sociological, linguistic patterns, etc. (HowelLs, 1966). In this context, it is necessary to make clear the biological, demographic, and breeding features of the populations concerned.

A series of reports were made on the distribution of blood polymorphisms in a Kamishima population (Toyomasu et al., 1977) and Toshi and Momotori populations (Toyomasu \& Katayama, 1978), and

* This work was supported by a grant from the Ministry of Education. on the breeding structure in the Kamishima population (KАтАу Aмa et al., 1978). In these reports, it was demonstrated that significant deviations were detectable in the blood polymorphic distributions of the three populations from the general population in Mie Prefecture and that probable effect of random genetic drift on blood polymorphic distribution in the Kamishima population was possible to be suggested.

These three populations are geographically close to one another and ecologically similar. In addition, there is a reason to believe that these populations were settled during the Kofun era, about 4-th 

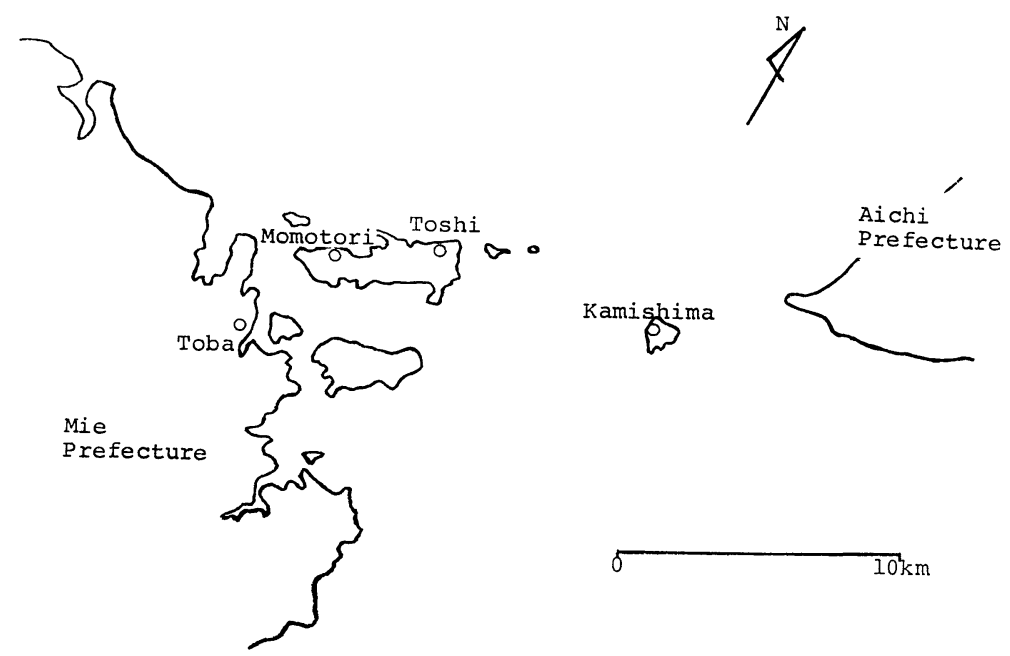

Fig. 1. The locations of the Kamishima, Toshi, Momotori, and Toba populations.

to 7-th century (NAKAOKA, 1970), and that, though their origins might be closely related with one another, there has been virtually no interchange between the $\mathrm{Ka}$ mishima and both Toshi-jima populations for a long time. The population sizes at present are about 1000, 2500 and 1500 for the Kamishima, Toshi and Momotori populations respectively. The locations of these populations and a Toba population are shown in Fig. 1.

The present paper attempts to view the relationships among the four populations, including the Toba population, from various points of view, and to analyze the main causes of genetic diversity by making up a picture representing the genetic allocation of the four populations*. In

* In later sections, the abbreviation will be made for these populations; KA, the Kamishima population; TOS, the Toshi population; $\mathrm{MO}$, the Momotori population; TOB, the Toba population. order to draw the picture, single measures of difference between populations, or distance measures, were used to represent genetic, geographic, and migrational variables and the correlations among these differences were examined.

\section{MIGRATIONAL DISTANCE}

In this paper, to measure the biological kin relationships, or migrational relationships, among KA, TOS, MO and TOB, an attempt was made to utilize the distribution of surnames in each population and a new measure will be proposed.

Assuming that persons having the same surname have descended from the same progenitor through the male line (in patrilineal societies) and that relationships through female lines and mixed lines are proportional to those through male lines, then it can be thought that the ratio of all possible pairs of identical surnames to all possible pairs of surnames within 
a population indicates the degree of inbreeding and that the frequency of surnames shared between two populations reflects the migrationa llineage and measures the degree of biological kin relationship between the populations. Thus, data on surname frequencies offer a helpful approach to the breeding distance between populations (GoODMAN \& LASKER, 1974) as well as to the inbreeding coefficient in a given population. From such a point of view, the frequency of pairs of spouses having the same surname (marital isonomy) has been used to estimate the inbreeding coefficient (CROW \& MANGE, 1965 ; YASUdA \& Furusho, 1971ab ; LASKER, 1969 ; KATAYAMA et $a l ., 1978)$ and the degree of genetic isolation (LASKER et al., 1972). The frequency of surnames shared between two populations has been applied to estimate a coefficient of relationship between the populations (LASKER, 1977) and an admixure rate (TAVERESNETo \& AzÉVÉDO, 1977).

As pointed out in the previous report (KAтAyAma et $a l ., 1978$ ), the surname is useful in estimating the inbreeding coefficient in the Kamishima population. The conditions are probably the same in the Toshi and Momotori populations, because we gained by personal communications the information that persons registered with the same surname in the Jinshin Koseki (1872), in which surnames were first adopted for all persons in Japan, had been in some degree of consanguinity. Therefore, it may be appropriate to estimate the biological kin relationships among the studied populations as well as to estimate the degree of inbreeding in each population, by means of the surname distributions.

The application of surname identity to measure the degree of biological kin relationship between populations requires the following assumptions: 1 . that all populations used for comparisons are in closer location, so that the same surname has descended from the same ancestor in any population, in other words, monophyly in surname; 2 . that the surname has been used for a comparatively long period of time and been seldom changed to an alternative one; and 3 . that the migration of genes is proportional to the migration of surname, that is, there is no significant tendency that males transmitting the surnames stay in the population in which they were born whereas females migrate more freely. As suggested by LASKer (1977), it is unnecessary in such an application to assume that patrilateral marriages are proportional to the total number possible through all lines. Under these conditions, the presence of the same surname in two populations can be traced to known migrants from one place to another or to both of them from a third place, and it can be said that the greater the similarity in the distributions of surnames, the closer the kin relationship between the populations is. Surname identity also is useful for determining recent common origin in special cases (LASKER, 1973) as well as for estimating such a mode of migration between populations.

The real situation may be somewhat 
Table 1. The number of total surnames and surnames shared with the other populations in each population.

\begin{tabular}{lccccc}
\hline \multirow{2}{*}{ Population } & No. of & \multicolumn{4}{c}{ No. of Surnames Shared with } \\
& Surnames & Kamishima & Toshi & Momotori & Toba \\
\hline Kamishima & 18 & - & 4 & 4 & 11 \\
Toshi & 33 & 4 & - & 6 & 17 \\
Momotori & 34 & 4 & 6 & - & 23 \\
Toba & 97 & 11 & 17 & 23 & - \\
\hline
\end{tabular}

Table 2. The frequency of persons having the surnames shared with the other populations in each population.

\begin{tabular}{|c|c|c|c|c|c|}
\hline \multirow{2}{*}{ Population } & \multicolumn{4}{|c|}{$\begin{array}{l}\text { The Frequency of Persons Having } \\
\text { Surnames Shared with }\end{array}$} & \multirow{2}{*}{ not Shared } \\
\hline & Kamishima & Toshi & Momotori & Toba & \\
\hline Kamishima & - & 0.087 & 0.136 & 0.672 & 0.328 \\
\hline Toshi & 0.216 & - & 0.721 & 0.835 & 0.165 \\
\hline Momotori & 0.057 & 0.346 & - & 0.827 & 0.173 \\
\hline Toba & 0.136 & 0.159 & 0.196 & - & 0.657 \\
\hline
\end{tabular}

deviating from these assumptions in the studied populations, especially in 3 , that is, females may migrate just a little more frequently. Since there is, however, no significance for such tendency, it may not become the reason to reject the assumption that surname migration is approximately proportional to gene flow.

Lists of surnames were collected for all inhabitants in KA, TOS and MO from the resident registers in 1975-1976 and from the list of shool children in TOB. Therefore, date were obtained from the very distributions of surnames in $\mathrm{KA}$, TOS and MO and from a sort of random sampling in TOB.

Table 1 gives the number of surnames and of the surnames shared with the other populations. Table 2 presents the frequency of persons having the surnames shared with other populations and of the persons having inherent surnames in each population. For the purpose of excluding the surnames of temporary inhabitants, the surnames which less than $0.2 \%$ of all inhabitants had were excluded from the number of surnames. From these tables, it can be noted: 1. that KA has the fewest number of surnames in all populations; 2 . that the frequencies of persons having inherent surnames are lower in TOS and MO than in $\mathrm{KA} ; 3$. that, in TOS, the frequencies of persons having the surnames shared with the other populations are highest in all combinations; and 4 . that both the number of shared surnames and the frequency of persons having shared surnames are largest in a combination of TOS and MO. From these results, it can be concluded that :

1. KA shows fewer surname exchanges with other populations than TOS and 
MO probably because of its higher isolation;

2. in TOS, almost all the surnames with higher frequency are shared with the other populations and this situation might have been brought about by the higher chances of these surnames spreading over the other populations when TOS expanded more rapidly than $\mathrm{KA}$ and $\mathrm{MO}$;

3. as can be expected from the geographic relationship, TOS and MO are likely to have the closest relationship in surname distribution probably because of inter-migration between the two;

4. the migrations between TOB and other three populations may have occurred exclusively toward TOB and KA may have sent fewer emigrants to TOB than TOS and MO.

As a method for measuring the degree of kin relationship between populations in terms of the identical surnames, LASKER (1977) proposed the coefficient of relationship, which can be calculated by taking half the ratio of all possible pairs of identical surnames to all possible pairs of surnames between populations. Lasker's measure is, however, inadequate in the case that there is a large difference in the rate of surname identity among the populations investigated. Therefore, in this paper, taking into account such difference, a sort of distance measure which evaluates the net surname difference between populations will be proposed and utilized for comparisons of KA, TOS, MO and TOB.

First, the rates of surname identity
Table 3. The ratio of all possible pairs of identical surnames to all possible of surnames $\left(J_{i j}\right)$ within and between the Kamishima, Toshi, Momotori, and Toba populations.

Kamishima Toshi Momotori Toba

\begin{tabular}{lllll}
\hline Kamishima & 0.2108 & & & \\
Toshi & 0.0067 & 0.1055 & & \\
Momotori & 0.0030 & 0.0351 & 0.0984 & \\
Toba & 0.0171 & 0.0109 & 0.0057 & 0.0060 \\
\hline
\end{tabular}

within $\left(J_{i i}\right)$ and between $\left(J_{i j}\right)$ populations, that is, the probabilities that two persons having identical surname are drawn from the same population and from the two different populations, respectively, are calculated;

$$
J_{i i}=\Sigma x_{a i}{ }^{2}, \quad J_{i j}=\Sigma x_{a i} x_{a j},
$$

where $x_{a i}$ is the frequency of the a-th surname in the $\mathrm{i}$-th population. Table 3 shows the matrix of the $J_{i i}$ and $J_{i j}$ values, or a sort of kinship coefficient, in the studied populations. $J_{i j}$ means the degree of relationship with respect to surname between the $\mathrm{i}$-th and $\mathrm{j}$-th populations and is equal to twice the coefficient of relationship proposed by LASKER (1977), and $J_{i i}$ becomes approximately equal to four times average inbreeding coefficient of the $i$-th population under the condition that a surname is monophyletic and that there is no assortative mating with respect to surname. It should be noted from the $J_{i i}$ values that both the TOS and MO are in about half the inbreeding state of $\mathrm{KA}$ and that TOB is in very low inbreeding state nearly of the same order as those detected in small cities in Japan (YASUDA $\&$ Furusho, 1971a). In addition, the degree of surname fixation can be indicated by 
the effective number of surnames (YASUDA et $a l ., 1974)$ derived from $J_{i i}$. The effective number of surnames $\left(n_{e}\right)$ is equal to the number of surnames that would be obtained if all surnames present had equal frequency and can be calculated as follows :

$$
n_{e}=\frac{1}{J_{i i}} .
$$

The $n_{e}$ values became 4.7, 9.5, 10.2 and 166.7 for KA, TOS, MO and TOB, respectively. $\mathrm{KA}$ is the smallest in $n_{e}$, so that KA shows the highest degree of surname fixation. The highest rate of surname identity is observable between TOS and MO and the lowest rate between KA and MO.

Second, the probability that two persons having different surnames are drawn from the same population and from two different populations can be defined as follows;

$$
\mathrm{D}_{i i}=1-J_{i i} \text {, and } \mathrm{D}_{i j}=1-J_{i j} \text {. }
$$

$\mathrm{D}_{i i}$ also indicates the degree of surname variability of the $i$-th population. It is easy to see in Table 3 that $\mathrm{KA}$ is by far less variable in surname distribution than the other populations. This may be due to the fixation toward a small number of surnames through isolation and inbreeding. Therefore, surname distribution also suggests that KA has been subject to the most intense isolation in the four populations.

Finally, we can define the measure which represents the distance relationships between the populations with respect to surname distribution, that is;

$$
d_{i j}=\mathrm{D}_{i j}-\frac{\mathrm{D}_{i \dot{i}}+\mathrm{D}_{j j}}{2}=\frac{J_{i i}+J_{j j}}{2}-J_{i j} .
$$

Table 4. The migrational distance $\left(d_{i j}\right)$ between the Kamishima, Toshi, Momotori, and Toba populations.

\begin{tabular}{llll}
\hline & Kamishima & Toshi & Momotori \\
\hline Kamishima & & & \\
Toshi & 0.1514 & & \\
Momotori & 0.1516 & 0.0669 & \\
Toba & 0.0993 & 0.0449 & 0.0465 \\
\hline
\end{tabular}

This measure indicates, in analogy to the "net codon difference" of NEI (1974), the net surname difference between the populations and can be called the migrational distance since the difference in this value may correspond to the difference in the degree of mode of migration in the past between the populations.

Table 4 shows the matrix of migrational distances $\left(d_{i, j}\right)$ between KA, TOS, MO and TOB obtained from the surname distributions. The $d_{i j}$ value between KA and $\mathrm{MO}$ is largest and that between TOS and TOB is smallest in all relationships, but TOS and MO hardly show significant differences in their $d_{i j}$ values not only from KA but also from TOB. It should be noted from Table 4 that the relationships between KA and both TOS and MO are migrationally most distant and that the relationship between TOS and TOB is closest.

These results are well compatible with what is known about the historical and demographic relations among the populations, so it can be concluded that this statistic may provide a good measure for comparing the degree of genetic exchange.

\section{GENETIC DISTANCE}

The genetic relationship between two 
populations can be expressed by a single number in the form of genetic distance. Several measures of so-called genetic distance between populations are now in common use. Although their properties and the relations between them are various, they can be roughly classified into two kinds of measures, the absolute type and the relative type. As a representative of the absolute type, there is Nei's measure (NEI, 1972), which is expressed as an estimate of average net codon difference per locus when the used loci are randomly sampled, and which is called the evolutionary distance since it enables us to estimate directly the separation time between populations under some assumptions. This method may be suitable for comparing the larger categories of taxonomy than sub-species. As relative measures, a number of methods have been proposed, of which the chi-square distance (SANGHVI, 1953), the chord distance (CAvalli-Sforza \& Edwards, 1967), and the R-matrix method (HARPENDING \& JENKINS, 1973) have been used by many investigators. These are often called the classificatory distances (NEI, 1977) or the Maharanobis type distances (SмIтH, 1977) and known to present values resembling one another.

For various reasons, in this paper, the genetic relationships between $\mathrm{KA}$, TOS, MO and TOB were examined in terms of the distance measure derived from the matrix of genetic kinship coefficients between populations (R-matrix). The procedure of this method has been outlined by Harpending \& Jenkins (1973).
The gene frequency data used for the calculation of genetic distance are derived from our previous reports on blood polymorphism distributions in the Kamishima population (Toyomasu et al., 1977) and in the Toshi and Momotori populations (Toyomasu \& Katayama, 1978). Since data for the Toba population have not been obtained, the data on corresponding blood polymorphisms obtained from the cities of Tsu and Yokkaichi in Mie Prefecture (MatsunaGa, ed. in-chief, 1975) were used as the substitute for them (these data correspond with Mie in our previous reports). Since these data were obtained from the general population which can be regarded as belonging to the marriage area including the Toba City, it is very plausible that they are used in place of data for the Toba population.

The genetic distances were calculated from the variability in 23 alleles of the 10 systems, $\mathrm{ABO}, \mathrm{Hp}, \mathrm{Tf}, \mathrm{AcP}, \mathrm{PGM}_{1}$, PGD, ADA, EsD, GPT, and GOT.

According to HARPENDING \& JENKINS (1973), the genetic kinship coefficient between groups $i$ and $j$ is given as

$$
r_{i j}=\frac{\left(P_{i}-\bar{P}\right)\left(P_{j}-\bar{P}\right)}{\bar{P}(1-\bar{P})} \text { for any allele. }
$$

In this expression, $\bar{P}$ is the average gene frequency of the allele in the study array. The matrix of genetic kinship coefficient is calculated for each allele, and these matrices are averaged to yield one overall genetic kinship matrix (R-matrix). The $\mathrm{R}$-matrix among the four populations is given in the lower triangle of Table 5 . Here, $\boldsymbol{r}_{i i}$ is nothing but the variance of 
Table 5. The matrices of genetic distances and kinship coefficients between the Kamishima, Toshi, Momotori, and Toba populations ( $R$ matrix), obtained from blood polymorphism gene frequency variances and covariances.

\begin{tabular}{lrrrr}
\hline & Kamishima & \multicolumn{1}{c}{ Toshi } & Momotori & Toba \\
\hline Kami shima & 0.00627 & 0.01895 & 0.01637 & 0.01283 \\
Toshi & -0.00370 & 0.00528 & 0.01230 & 0.01196 \\
Momotori & -0.00211 & -0.00057 & 0.00588 & 0.01592 \\
Toba & -0.00095 & -0.00101 & -0.00269 & 0.00466 \\
\hline
\end{tabular}

Note....Upper triangular matrix: genetic distances between the populations, and lower triangular matrix: kinship coefficients between and within the populations.

gene frequency of the $i$-th population around the total average and $\boldsymbol{r}_{i j}$ the covariance of gene frequency of the $i$-th and $j$-th populations; therefore $\boldsymbol{r}_{i i}$ also indicates the extent of deviation of gene frequency from the total average. It should be noted that the $r_{i i}$ values may be proportional of the sizes of these populations. This fact demonstrates that the genetic variation among the four populations has been caused more or less by random factors depending on population size.

From the genetic kinship coefficients $\left(\boldsymbol{r}_{i j}\right)$, a measure of genetic distance between the populations $i$ and $j$ is given as

$$
d_{i j}=\boldsymbol{r}_{i i}+\boldsymbol{r}_{j j}-2 \boldsymbol{r}_{i j} .
$$

The genetic distances $\left(d_{i j}\right)$ between the four populations are given in the upper triangle of Table 5. It is suggested that TOS and TOB are genetically closest to each other and $\mathrm{KA}$ and MO most separated from each other in all pairs of populations. According to HARPENDING \& Jenkins(1973), this distance measure is nearly equivalent to the chi-squared statistics and Morton's hybridity (MORTON, 1974). However, it is preferable to compute first the matrix of genetic kinship coefficients, because the eigenvectors of this matrix give a genetic

Table 6. Eigenvectors in principal component analysis of the blood polymorphism relationship matrix.

\begin{tabular}{lrrr}
\hline \multirow{2}{*}{ Population } & \multicolumn{3}{c}{ Eigenvectors } \\
\cline { 2 - 4 } & \multicolumn{1}{c}{1} & \multicolumn{1}{c}{3} \\
\hline Kamishima & 0.06757 & 0.03140 & -0.02675 \\
Toshi & -0.05045 & -0.03902 & -0.03489 \\
Momotori & -0.04767 & 0.05527 & 0.02347 \\
Toba & 0.03055 & -0.04765 & 0.03817 \\
\hline Eigen Value & 0.01032 & 0.00783 & 0.00394 \\
Cumulative & & & $100 \%$ \\
Percent of & $46.7 \%$ & $82.2 \%$ & \\
Total Variances & & & \\
\hline
\end{tabular}


map of populations.

Subsequently, usineg the procedure described by HARPENDING \& JENKINS (1973), the R-matrix among the four populations was subjected to a principal component analysis and the genetic relationships among the four populations were depicted. The three eigenvectors of the R-matrix are given in Table 6, along with the corresponding eigenvalues. Table 6 shows that the first principal component accounting for $47 \%$ of total variance separates the 4 populations into two groups, that is, one is the KA and TOB group and the other TOS and MO group. The former has a positive coefficient on this component, while the latter has a negative score. The second component, which accounts for substantially less variation than the first, separates KA and MO from TOS and TOB, in contrast with first component. The third component separates $\mathrm{KA}$ and TOS from $\mathrm{MO}$ and TOB. Thus, different principal components give thoroughly contradictory restults of grouping the four populations.

Table 7. Eigenvectors for alleles in principal component analysis of the blood polymorphism relationship matrix.

\begin{tabular}{|c|c|c|c|}
\hline \multirow{2}{*}{ Allele } & \multicolumn{3}{|c|}{ Eigenvectors } \\
\hline & 1 & 2 & 3 \\
\hline $\mathrm{I}^{\mathrm{A}}$ & -0.05755 & 0.02048 & -0.00260 \\
\hline $\mathrm{I}^{\mathrm{B}}$ & 0.02098 & 0.00136 & 0.05885 \\
\hline $\mathrm{I}^{\mathrm{O}}$ & 0.03648 & -0.01894 & -0.04054 \\
\hline $\mathrm{Hp}^{1}$ & -0.04073 & -0.11389 & -0.01428 \\
\hline $\mathrm{Hp}^{2}$ & 0.04073 & 0.11389 & 0.01428 \\
\hline$T f^{C}$ & -0.04135 & -0.03498 & -0.01809 \\
\hline$T f^{D}$ & -0.01303 & 0.03371 & 0.04095 \\
\hline $\operatorname{Tf}^{B}$ & 0.08239 & 0.00924 & -0.02944 \\
\hline $\mathrm{P}^{\mathrm{A}}$ & 0.02754 & 0.00894 & -0.00335 \\
\hline $\mathrm{P}^{\mathrm{B}}$ & -0.02796 & -0.00817 & 0.00248 \\
\hline $\mathrm{PGM}_{1}{ }^{1}$ & 0.02750 & -0.07595 & -0.01717 \\
\hline $\mathrm{PGM}_{1}^{2}$ & -0.01210 & 0.07939 & 0.02891 \\
\hline $\mathrm{PGM}_{1}$ var. & -0.06089 & -0.00740 & -0.04927 \\
\hline $\mathrm{Gpt}^{1}$ & -0.04918 & -0.05778 & 0.04497 \\
\hline $\mathrm{Gpt}^{2}$ & 0.04883 & 0.05842 & -0.04568 \\
\hline PGDA & 0.00625 & -0.00885 & 0.08165 \\
\hline $\mathrm{PGD}^{\mathrm{C}}$ & -0.00625 & 0.00885 & -0.08165 \\
\hline $\mathrm{EsD}^{1}$ & -0.06519 & 0.06437 & -0.01491 \\
\hline $\mathrm{EsD}^{2}$ & 0.06519 & -0.06437 & 0.01491 \\
\hline $\mathrm{ADA}^{1}$ & 0.14193 & -0.00545 & -0.00096 \\
\hline $\mathrm{ADA}^{2}$ & -0.14193 & 0.00545 & 0.00096 \\
\hline Got $^{1}$ & -0.03319 & 0.04103 & -0.01319 \\
\hline Got $^{\text {va }^{*}}$ & 0.03319 & -0.04103 & 0.01319 \\
\hline Eigenvalue & 0.07919 & 0.06006 & 0.03020 \\
\hline Cumulative & $46.7 \%$ & $82.2 \%$ & $100 \%$ \\
\hline
\end{tabular}


The eigenvalues of different genes associated with these three principal components are shown in Table 7 . The first component is especially strongly associated with the ADA genes, $\mathrm{Tf}^{\mathrm{B}}, \mathrm{PGM}_{1}{ }^{\mathrm{var}}$, and the EsD genes; the second component with the $\mathrm{Hp}$ genes, $\mathrm{PGM}_{1}{ }^{1}, \mathrm{PGM}_{1}{ }^{2}$, and the $\mathrm{EsD}$ genes; and the third component with the PGD genes. The $\mathrm{ADA}^{2}, \mathrm{Tf}^{\mathrm{B}}$, and $\mathrm{PGM}_{1}{ }^{\mathrm{var}}$ genes associated with the first component are relatively rare alleles and the reason for their associations is that the frequencies of $\mathrm{ADA}^{2}$ and $\mathrm{PGM}_{1}{ }^{\text {Var. }}$ genes are commonly high and that the frequency of $\mathrm{Tf}^{\mathrm{B}}$ gene is commonly low in TOS and MO. Taking into account these facts and the evidence for the high kin relationship between TOS and MO presented in Table 3, the first principal component accounting for the highest variance probably reflect the variation caused by intermigration rather than random variation. On the contrary, the second and third components presumably correspond to random variations.

By plotting in a plane the scaled eigenvectors of two of these components, we can get a diagram representing the genetic relation among the four populations. Fig. 2 shows such diagrams; the four populations are plotted on the first two principal components which account for $82.2 \%$ of total variance (A) and plotted on the first and third principal components which account for $64.5 \%$ of total variance (B). It follows from these diagrams that, although only $\mathrm{KA}$ is slightly deviating, the four populations generally are scattered in a considerably independent fa- shon. This means that, genetically, there is no specially close relationship with any pair of the four populations. Such a situation is characteristic where genetic diversity among populations is caused by random genetic drift. This suggests that the second and third principal components. accounting for $53.3 \%$ of total variance together, correspond to random variation.

\section{GEOGRAPHIC DISTANCE}

Geographic distance can be measured in various ways. In this paper, the crude distances in kilometers were measured along straight lines connecting the centers of populations from the 1: 50,000 map (published by Kokudo-Chiriin in Japan, 1970). Although it has been said that the crude distance measure is irrelevant in many cases since it ignores geographic barriers to population movement (Workman \& Niswander, 1970), this method is useful enough if people can move by sea as in the area studied in the present paper. The geographic distances between the four populations are presented in Table 8.

Table 8. Crude geographic distances between the four populations in kilometers.

\begin{tabular}{lccr} 
& Toshi & Momotori & Toba \\
\hline Kamishima & 7.73 & 12.44 & 14.70 \\
Toshi & & 4.83 & 7.76 \\
Momotori & & & 4.09 \\
\hline
\end{tabular}

\section{DISCUSSION}

For comparison of the genetic, migrational and geographic distance relationships between the populations, dendro- 
A.

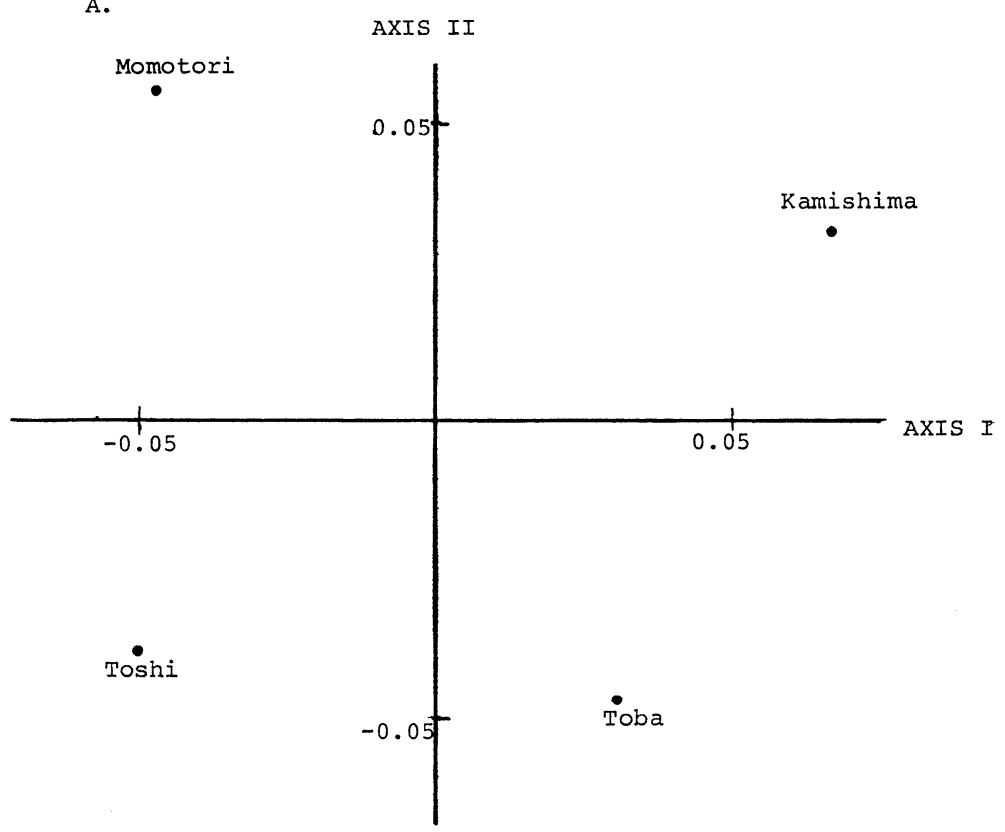

B.

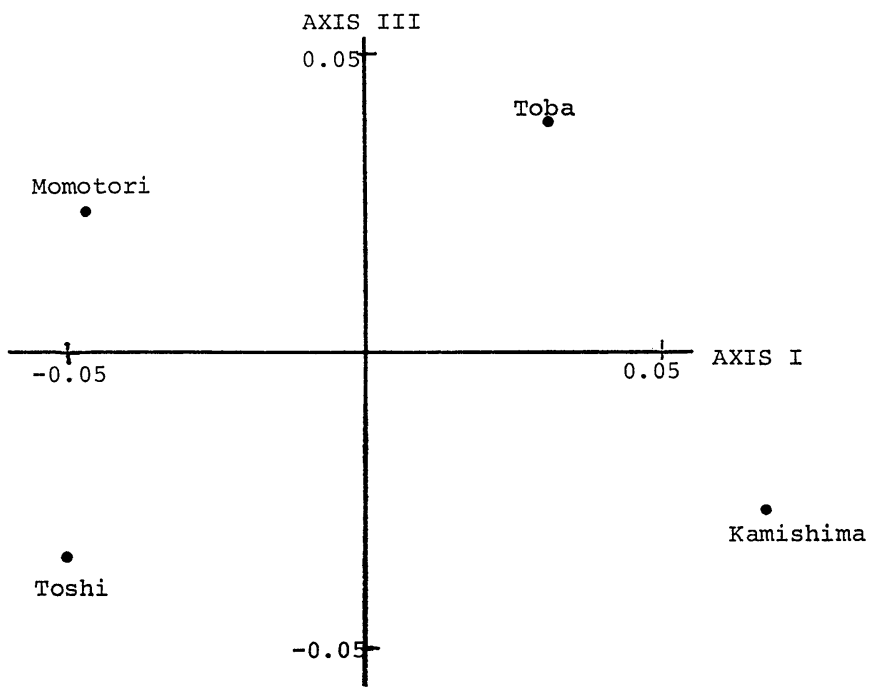

Fig. 2. Eienvector diagrams based on R matrix. A : plot of the four populations on first two scaled eigenvectors; B : plot on first and third scaled eigenvectors. 
A.

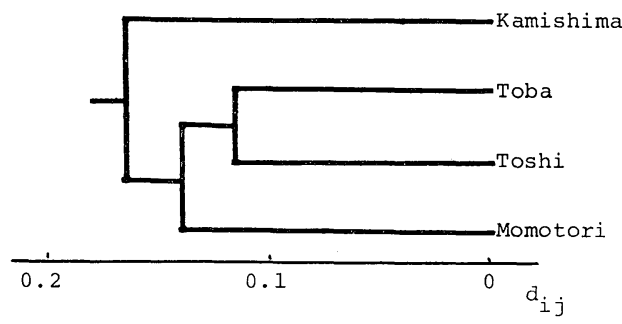

B.

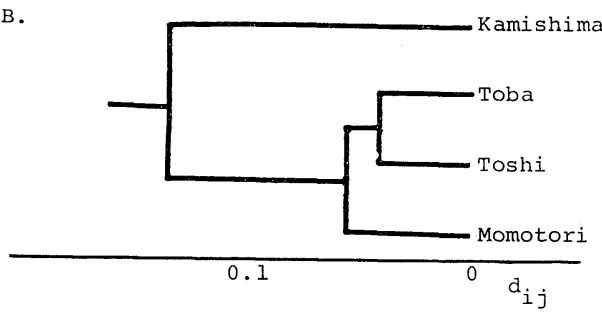

Fig. 3. Dendrograms (clustering by the method of Nei, 1975) for the Kamishima, Toshi, Momotori, and Toba populations. A : genetic distance; B: migrational distance.

grams were constructed based on the matrices of both genetic and migrational distances, and the correlation coefficients between geographic, genetic and migrational distances were examined.

Both dendrograms were constructed according to the clustering method of NEI, (NEI, 1975) and are shown in Figs. 3A and B. A shows the genetic distance relationships and $B$ the migrational distance relationships. It should be noted that both dendrograms, independently obtained, reveal striking similarity in their patterns though the relative lengths of branching are slightly different. This suggests that the genetic diversity among the four populations has, more or less, been influenced by interpopulational migration, and also that, in the studied area, surname distribution can readily give some useful information on the extent of the genetic effect of past migrations for an intermediate period of time between those given by the pedigree and the genetic marker as pointed out by LASKER (1977). Also from Figs. $3 A$ and $B$ as well as from the previous diagrams, we can obtain the picture in which $\mathrm{KA}$ is somewhat distant from the other populations, that is, TOS, MO and TOB are clustered into one side and only $\mathrm{KA}$ is situated on the other side.

The extent to which the genetic affinity between populations is related to the geographic proximity and to the intermigrational relationships can be determined by examining the correlation between the genetic, geographic and migrational distances for different combinations of populations. The correlation coefficients between the genetic, migrational and geographic distances for the four populations are presented in Table 9 . The results obtained from Table 9 are as follows:

1. The correlation coefficient between genetic and migrational distances was found to be about 0.69 ; therefore approximately $47 \%$ of the genetic variation can be ascribed directly to the difference in interpopulational migration. This value which is considered to be associated with migration is strikingly in accord with that obtained by the principal component analysis

Table 9. The correlation coefficients among geographic (GEO), genetic (GEN), and $\mathrm{mi}^{-}$ grational (MIG) distances.

\begin{tabular}{ccc}
\hline & GEN & MIG \\
\hline GEO & 0.1357 & 0.5453 \\
GEN & & 0.6878 \\
\hline
\end{tabular}


in the previous section.

2. While there seems to be no correlation between the genetic affinity and geographic proximity; this situation means that the island model is suitable for interpreting the genetic diversity within the studied area rather than the model of isolation by distance.

3. Also between the geographic and $\mathrm{mi}^{-}$ grational distances, there seems to be a positive correlation although smaller than that between the genetic and $\mathrm{mi}$ grational distances; that is, in this area, inter-populational migration depends more or less on the geographic proximity between the populations. This suggests that, in this area, there may be no specially close pairwise relationship of populations with respect to such inter-migration as marriage partner exchange, and that the relatively strong relationship of inter-migration between TOS and MO is probably due to the relatively near location of them.

There have been some reports from the world on the correlation between genetic and geographic distances. A positive correlation was reported in the case of Papago Indian (Workman \& NiswaNDER, 1970), but no correlation in Bougainville islanders (FrIEDLAENDER, 1975). In the latter case, the genetic diversity among populations has been interpreted the cause by mainly random genetic drift. It is plausible that, in the studied area, random genetic drift has largely influenced the genetic diversity as suggested in the preceding section.

Few examples have been reported from
Japan, which show a considerably large amount of genetic diversity among populations scattered in so limited an area. In the case of the studied area, it was already suggested in the previous reports (Toyomasu $e t$ al., 1977 ; Katayama $e t$ al., 1978) that random genetic drift through extraordinarily strong isolation most likely played an impotant role in the formation of such genetic diversity. The cause of isolation may be by the intervening sea; that is, the sea may have become a barrier to movement and impeded gene flow, so that random genetic drift may have surpassed in magnitude the exchange of gene. In general, movement by sea is said to be more difficult than movement on land. KIRK et al. (1972) suggested in their genetic study of Australian Aboriginals that sea barrier is more effective than land barrier. Since, in the case of the studied area however, the sea intervening between populations is too narrow for fishermen to come and go, it may have operated as a sociological barrier rather than as a geographical barrier. This is also partly supported by the result that the genetic affinity does not depend on the geographic proximity.

\section{SUMMARY}

The genetic affinity, migrational relationship, and geographic proximity between the Kamishima, Toshi, Momotori and Toba populations, Mie Prefecture, were examined by distance analysis and discussed with special reference to the pattern of genetic diversity among these populations. In order to measure the degree of 
migrational relationships between the populations, a new statistic of breeding distance, which was called the migrational distance here, was adopted using the surname distribution in each population. The genetic affinity was examined by the method of HARPENDING \& JENKINS (1973), which enabled us to depict at the same time the dendrogram and diagram representing the current genetic relationships. Further, the correlations were examined between the genetic, migrational, and geographic distances separating the populations. The results so far obtained are as follows:

1. The migrational relationships were found that the Kamishima population was somewhat distant from the other populations which were in considerably close relation with one another.

2 . Since the migrational distance relationships were well compatible with what is known about the historical and demographic relations among the populations, this statistic may provide a good indicator for comparing the degree of genetic interchange.

3. The genetic distance analysis revealed that, although the Kamishima population was just a little deviating, these populations were considerably independent of one another and that there was no specially close relation between any pair of the populations.

4. The dendrograms constructed based on both genetic and migrational distances displayed a striking similarity with each other in their clustering patterns, though the relative lengths of branch- ing were slightly different.

5. The genetic distance seems to have a correlation coefficient of 0.69 with migrational distances but little correlation with geographic distances; therefore island model is suitable for interpreting the genetic diversity among these populations.

6. It can be concluded that the pattern of current genetic diversity among these populations may be derived mostly from the difference in interpopulational migration and from random genetic drift; about half of genetic variation may be attributed to the variation caused by interpopulational migration and the remaining half to random variation.

\section{ACKNOWLEDGEMENT}

The authors are indebted to Professor Hideo Matumoto and Dr, Yoshihiro TAMAKI, Department of Legal medicine, Osaka Medical School, for their encouragement and to Mr. Akira TAgaya, Department of Anatomy, Osaka City University Medical School, for his useful suggestion and computer programming. Special thanks are also due to the people living in Kamishima and Toshi-jima islands and the Board of Education of Toba City for their corporation to this study.

\section{REFERENCES}

CAVAlli-SForza, L. L. and A. W.F. EdwARDS, 1967: Phylogenetic analysis: models and estimation procedure. Am. J. Hum. Genet., $19: 233-257$.

Crow, J. F. and A. P. MANGe, 1965: Measurement of inbreeding from the frequency of 
marriage between persons of the same sur name. Eugen. Quart., 12: 199-203.

FRIEDLAENDER, J. S., 1975: Patterns of Human Variation: The Demography, Genetics, and Phenetics of Bougainville Islanders, Harvard Univ. Press, Canbridge.

Goodman, M. and G. W. LAseer, 1974: Measurement of distance and propinquity in anthropological studies. Genetic Distance, J. F. Crow \& C. Denniston eds., Plenum Press, New York, 5-22.

Herpending, H. and T. Jenkins, 1973: Genetic distance among Southern African populations. Methods and Theories of Anthropological Genetics, M. H. Crowford \& P. L. Workman eds., Univ. of New Mexico Press, 177-199.

Howells, W. W.. 1966: Population distances: biological, linguistic, geographical, and environmental. Curr. Anthrop., 7 : 531-540.

Katayama, K., T. TOYomasu and H.MATSUмото, 1978: Genetic study on the local populations in Mie Prefecture. II. Population structure in Kamishima Island. J. Anthrop. Soc. Nippon, 86: 83-94. (in Japanese, with English summary)

KIRK, R. L., L. D. SANGHVI and V.BALAKRISHNAN, 1972: A further study of genetic distance among Australian Aborigines: nine tribes in the Northern Territory. Humangenetik, 14: 95-102.

LASKER, G. W. 1969: Isonymy (recurrence of the same surnames in affinal relatives): A comparison of rates calculated from pedigrees. Hum. Biol., 41: 309-321.

LASKER, G. W., 1973: Human genetic distances and human mating distances. Methods and Theories of Anthropological Genetics, M. H. Crowford \& P. L. Workman eds., Univ. of New Mexico Press, 151-157.

LASKER, G. W., 1977 : A coefficient of relationship by isonymy, a method for estimating the genetic relationship between populations. Hum. Biol., 49: 489-493.

Lasker, G. W., B. Chiarelli, M. Masali, F. FEDELE and B. A. KAPLAN, 1972: Degree of human genetic isolation measured by isonymy and marital distances in two communities in an Italian Alpine valley. Hum. Biol., 44 : 351-360.

MatsunaGa, E. (ed. in-chief), 1975: Distribution of polymorphic traits in the Japanese and neighbouring populations. Anthropological and Genetic Study on the Japanese, Part II, Japanese Committee for the International Biological Program, Univ. of Tokyo Press, 71-204.

Morton, N. E., 1974. Kinship bioassay. Genetic Distance, J. F. Crow \& C. Denniston eds., Plenum Press, New York, 97-104.

NakAOKA, S., (ed.) 1970: Toba Shima Shinshi. Toba City. (in Japanese)

NEI, M., 1972: Genetic distance between populations. Amer. Nat., 106: 283-292.

NEI, M., 1974: A new measure of genetic distance. Genetic Distance, J.F. Crow \& C. Denniston eds., Plenum Press, New York, 63-76.

Ner, M., 1975: Molecular Population Genetics and Evolution. North-Holland Press, Amsterdam and New York.

NEI, M., 1977 : Genetic distance. Iden, K. Omoto \& E. Matsunaga eds., Yuzankaku, Tokyo, 29-62. (in Japanese)

SANGHVI, L.D., 1953 : Comparison of genetical and morphological methods for a study of biological differences. Am. J. Phys. Anthrop., 11: 385-404.

Smith, C. A. B., 1977: A note on genetic distance. Ann. Hum. Genet., 40: 463-479.

TAvares-NÉto, J. and E. S. AzÉvédo, 1977 : Racial origin and historical aspects of family names in Bahia, Brazil. Hum. Biol., 49: 287-299.

Toyomasu, T., K. Katayama, T. Miyazaki and H. MAtsumoto, 1977 : Genetic study on the local populations in Mie Prefecture. I. Blood component polymorphisms in $\mathrm{Kami}$ shima Island. J. Anthrop. Soc. Nippon, 85 : 311-323.

Toyomasu, T. and K. KAтAyAma, 1978: Genetic study on the local populations in $\mathrm{Mie}$ Prefecture. III. Blood component polymorphisms in Toshi-jima Island. J. Anthrop. Soc. 
Nippon, 86: 71-76.

YASUdA, N. and T. Furusho, 1971a: Random and nonrandom inbreeding revealed from isonymy study. I. Small cities of Japan. Am. J. Hum. Genet., 23: 303-316.

Yasuda, N., L.L. Cavalli-SForza, M. SkolNICK and A Moroni, 1974: The evolution of surname: an analysis of their distribu- tion and extinction. Theoret. Popul. Biol., 5: 123-142.

WorkMAN, P. L. and J. D. NisWANDER, 1970 : Population studies on southwestern Indian tribes. II. Local genetic differentiation in the Papago. Am. J. Hum. Genet., 22: 24-49.

(Received October 2,1978)

\title{
三重県離島における遺伝学的研究
}

IV 神島, 答志, 桃取および鳥羽の 4 集団間における集団遣伝学的諸関係について

\author{
片山一道 - 豊増 翼 \\ 大阪医科大学 法医学教室
}

報告者引は，三重県鳥羽市に属する神島，答志および桃取地区で集団遺伝学的調查を行い，乙れまでに，多 型性形質の分布と集団構造についての報告を行ってきたが，本報では，てれら 3 集団に鳥羽地区を加えた 4 集 団について, 遺伝的距離, “親縁的”距離掞よび地理的距離を求め, 各々の集団の間にみられる集団遺伝学的諸 関係について検討を加えるとともに, 集団間の遺伝的変異の特性を明らかにした。遺伝的距離は, Harpending と Jenkins (1973) の方法によって, まだ親縁的”距離は姓の分布を利用した新しい方法によって推定 された。ての両距離については, 比較を容易にするために, dendrogram と diagram が作成された。さら に, 遺伝的距離, “親縁的”距離㧍よび地理的距離の間で相関関係が検討された。以上の分析と考察とから次 の成績が得られた。

1. 姓の分布を利用して得られた “親縁的”距離は, 乙れらの集団間の歴史的, 人口学的諸関係についての従 来の知見とよく合致しており，集団間の交流の比較に有効な指標を与えることができると考えられる。

2. 遺伝的距離の分析から, これらの集団間の遺伝的関係は, 神島のみ僅が隔っているが, いずれもほぼ等 しい間隔で存在しており，特に近縁な集団対は認められなかった。

3. 遺伝的距離抢よび “親縁的”距離に基づいた $2 つ の$ dendrog rams は，分岐の相対的位置の違いを除く と，相互によく似たパターンを示した。

4. 遺伝的距離は, “親縁的”距離との間には相関が見られた $(r=0.69)$ が, 地理的距離との間には相関が見 られなかった。とのととは，乙れら集団間の遺伝的変異には島モデルの適用が応しいととを示唆する。

5. 乙れら 4 集団の間に存在する遺伝的変異は, 集団間の交流量の差異と random genetic drift に㴆因し ており, 遺伝的変異のほぼ $50 \%$ が inter-migration に帰因した変異に, 残りの $50 \%$ が random な変 異に対応するあのと考察される。 